\title{
SOSIALISASI DAN HARMONISASI GERAKAN MASYARAKAT HIDUP SEHAT (GERMAS) DENGAN PROGRAM INDONESIA SEHAT DENGAN PENDEKATAN KELUARGA (PIS-PK) PADA AWAL MASA PANDEMI COVID-19 DI TAMBUN BEKASI
}

\author{
Ita Astit Karmawati ${ }^{1}$, Tarwoto $^{2}$, Ita Yulita ${ }^{3}$, Sri Handayani $^{4}$, Elsye Rahmawaty ${ }^{5}$, Vera Suzana Dewi Haris ${ }^{6 凶}$ \\ Coreponding author: vera_sdh@yahoo.co.id \\ 1,3 Jurusan Keperawatan Gigi, Poltekkes Kemenkes Jakarta I, Indonesia \\ 2,5 Jurusan Keperawatan, Poltekkes Kemenkes Jakarta I, Indonesia \\ 4,6 Jurusan Kebidanan, Poltekkes Kemenkes Jakarta I, Indonesia
}

Genesis Naskah: Submitted: 11-10-2021, Revised: 26-10-2021, Accepted: 02-11-2021

\begin{abstract}
Abstrak
Gerakan Masyarakat Hidup Sehat (GERMAS) merupakan tindakan yang sistematis dan terencana yang dilakukan secara bersama-sama dengan kesadaran, kemauan, dan kemampuan berperilaku sehat untuk meningkatkan kualitas hidup. Pelaksanaan GERMAS harus dimulai dari keluarga, karena keluarga adalah bagian terkecil dari masyarakat yang membentuk kepribadian. Germas dapat dilakukan dengan berbagai cara seperti melakukan aktivitas fisik, mengkonsumsi sayur dan buah, tidak merokok, tidak mengkonsumsi alkohol, memeriksa kesehatan secara rutin, membersihkan lingkungan, dan menggunakan jamban. Metode kegiatan pengabdian masyarakat yaitu pada tahap awal, GERMAS secara nasional dimulai dengan berfokus pada tiga kegiatan, yaitu: melakukan aktivitas fisik 30 menit per hari, konsumsi sayur dan buah, serta cek kesehatan secara rutin. Poltekkes Kemenkes Jakarta 1 mengambil peran dalam mensukseskan program germas ini dengan melakukan kegiatan pengabdian kepada masyarakat melalui "Sosialisasi dan Harmonisasi Gerakan Masyarakat Hidup Sehat (GERMAS) dengan Program Indonesia Sehat melalui pendekatan keluarga (PIS-PK). Kegiatan ini dilaksanakan selama setengah hari pada tanggal 16 Maret 2020 bertempat di Gedung PGRI J. Kalimaya I Blok B Metland, Kec Tambun Bekasi, Jawa Barat. Pada kegiatan pengabdian kepada masyarakat kali ini difokuskan pada budaya makan buah sehingga seluruh konsumsi yang disediakan panitia baik untuk snack maupun makan siang adalah buah-buahan sedangkan senam Bersama didahului dengan pemanasan yoga dan senam bersama. Kegiatan GERMAS ditambahkan penyuluhan menjaga protokol kesehatan dengan memutarkan video cara memakai masker, mencuci tangan dan sosial distancing karena untuk mencegah masyarakat tertular virus COVID-19 yang baru melanda Indonesia. Hasil kegiatan pengabdian masyarakat ini adalah diikuti oleh sebanyak 210 orang karyawan/karyawati pabrik di Wilayah Tambun Bekasi.
\end{abstract}

Kata Kunci : Gerakan masyarakat, program, Indonesia sehat, pendekatan keluarga.

\section{SOCIALIZATION AND HARMONIZATION OF THE MOVEMENT OF A HEALTHY COMMUNITY MOVEMENT (GERMAS) WITH THE HEALTHY INDONESIA PROGRAM WITH A FAMILY APPROACH (PIS-PK) AT THE EARLY TIME OF THE COVID-19 PANDEMIC IN TAMBUN BEKASI}

\begin{abstract}
The Healthy Living Community Movement is a systematic and planned action that is carried out together with awareness, willingness, and ability to behave in a healthy manner to improve the quality of life. The implementation of GERMAS must start from the family, because the family is the smallest part of society that forms the personality. Germas can be done in various ways such as doing physical activity, consuming vegetables and fruit, not smoking, not consuming alcohol, checking health regularly, cleaning the environment, and using latrines. The method of community service activities is that in the early stages, Community Movement nationally begins by focusing on three activities, namely: doing 30 minutes of physical activity per day, consuming vegetables and fruit, and having regular health checks. Poltekkes Kemenkes Jakarta 1 took a role in the success of this Germas program
\end{abstract}


by carrying out community service activities through "Socialization and Harmonization of the Healthy Living Community Movement with the Healthy Indonesia Program through a family approach. This activity was carried out for half a day on March 16, 2020 at the PGRI J. Kalimaya I Blok B Metland Building, Tambun Bekasi District, West Java. In this community service activity, it is focused on the culture of eating fruit so that all consumption provided by the committee for both snacks and lunch is fruit. While the joint exercise was preceded by a yoga warm-up and joint exercise. The Community Movement activity was added with counseling to maintain health protocols by playing videos on how to wear masks, wash hands and social distancing because to prevent people from contracting the COVID-19 virus that has just hit Indonesia.. The results of this community service activity were attended by 210 factory employees in the Tambun Bekasi area.

Keywords: Community movement, program, healthy Indonesia, family approach.

\section{Pendahuluan}

Saat ini, Indonesia tengah menghadapi tantangan besar yakni masalah kesehatan triple burden, karena masih adanya penyakit infeksi, meningkatnya penyakit tidak menular (PTM) dan penyakit-penyakit yang seharusnya seudah teratasi muncul kembali. Pada era 1990, penyakit menular seperti ISPA, Tuberkulosis dan Diare merupakan penyakit terbanyak dalam pelayanan kesehatan. Namun, perubahan gaya hidup masyarakat menjadi salah satu penyebab terjadinya pergeseran pola penyakit (transisi epidemiologi). Tahun 2015, PTM seperti Stroke, Penyakit Jantung Koroner (PJK), Kanker dan Diabetes justru menduduki peringkat tertinggi (Kemkes, 2016).

Gerakan Masyarakat Hidup Sehat (GERMAS) merupakan gerakan nasional yang diprakarsai oleh Presiden RI yang mengedepankan upaya promotive dan preventif, tanpa mengesampingkan upaya kuratifrehabilitatif dengan melibatkan seluruh komponen bangsa dalam memasyarakatkan paradigma sehat. Untuk menyukseskan GERMAS, tidak bisa hanya mengandalkan peran sector kesehatan saja. Peran Kementerian dan Lembaga di sector lainnya juga turut menentukan, dan ditunjang peran serta seluruh lapisan masyarakat. Mulai dari individu, keluarga, dan masyarakat dalam mempraktekkan pola hidup sehat, akademisi, dunia usaha, organisasi kemasyarakatan, dan organisasi profesi dalam menggerakkan anggotanya untuk berperilaku sehat; serta pemerintah baik di tingkat pusat maupun daerah dalam menyiapkan sarana dan prasarana pendukung, memantau dan mengevaluasi pelaksanaannya (Kementrian Kesehatan Republik Indonesia, 2018).

Pemerintah telah menetapkan pandemic Corona Virus Disease 2019 (COVID-19) sebagai bencana non-alam. Sejak diumumkannya kasus konfirmasi pertama pada Maret 2020, dalam rentang waktu satu bulan, seluruh provinsi telah melaporkan kasus konfirmasi. Penyebaran COVID-19 tidak hanya terjadi di Daerah Khusus Ibukota Jakarta dan kota padat penduduk lainnya, namun telah menyebar hingga ke pedesaan di daerah terpencil. Sampai dengan tanggal 27 Desember 2020, sebanyak 706.837 kasus konfirmasi COVID-19 telah dilaporkan di Indonesia dan tercatat sejumlah 20.994 orang meninggal (Tim Kerja Kementerian Dalam Negeri, 2013).

Oleh karena itu, Kementerian Kesehatan RI secara khusus mengingatkan masyarakat untuk menjaga kesehatan dan menjaga protokol kesehatan. Poltekkes Kemenkes Jakarta I sebagai UPT Teknik di bawah BPPSDM Kesehatan RI turut mengambil peran melalui pengabdian kepada masyarakat Gerakan Masyarakat Hidup Sehat (GERMAS) guna mewujudkan Indonesia 
sehat dengan meningkatkan kesehatan masyakat dan mencegah tertularnya masyarakat dari virus COVID-19 dengan sosialisasi dan penyuluhan menjaga protokol kesehatan selalu memakai masker, mencuci tangan serta sosial distancing.

Tujuan kegiatan pengabdian masyarakat ini adalah untuk mensosialisasikan senam GERMAS dan membudayakan makan buah bagi aktifitas sehari-hari dan sosialisasi cara mencegah tertular virus COVID-19.

\section{Metode Pelaksanaan}

Metode pengabdian berupa sosialisasi dan harmonisasi germas dengan PIS-PK. Sasaran khalayak adalah karyawan/karyawati pabrik di wilayah Tambun Bekasi, Jawa Barat sebanyak 210 orang. Sebelum memasuki Gedung tempat pelaksanaan GERMAS, seluruh panitia dan peserta GERMAS dilakukan pengecekan suhu. Realisasi kegiatan pengabdian masyarakat ini adalah dilakukannya dengan susunan acara sebagai berikut:

1. Menyanyikan lagu Indonesia Raya, Mars Germas

2. Doa

3. Sambutan Wakil Direktur I Poltekkes Kemenkes Jakarta I

4. Sosialisasi pemutaran video cara memakai masker, mencuci tangan, dan sosial distancing.

5. Materi sosialisasi germas oleh anggota DPR komisi IX

6. Penandatanganan komitmen bersama

7. Senam peregangan

8. Makan buah bersama

\section{Hasil dan Pembahasan}

Jumlah peserta dan Tim pengabdian masyarakat yang hadir sebanyak 210 orang dari target jumlah 300 peserta. Peserta sangat antusias dalam mengikuti sosialisasi germas terutama saat senam germas. Peserta dibudaya makan buah sehingga seluruh konsumsi yang disediakan panitia baik untuk snack maupun makan siang adalah buah-buahan. Sosialisasi GERMAS juga ditambahkan tentang cara pencegahan tertular COVID-19 dengan memutarkan video cara cara memamaki masker, mencuci tangan yang baik dan social distansing.

Gerakan Masyarakat Hidup Sehat (GERMAS) merupakan upaya promotif dan preventif guna meningkatkan pola hidup sehat di masyarakat. GERMAS didukung oleh kebijakan Presiden dalam peraturan Instruksi Presiden RI Nomor 1 Tahun 2017. Harapan dengan adanya GERMAS adalah untuk menurunkan angka kematian dan kesakitan yang disebabkan karena perilaku masyarakat yang tidak sehat (Cahyani et al., 2020). Kegiatan ini diharapkan dapat memberikan pengetahuan dan pemahaman karyawan dan karyawati pabrik di Wilayah Tambun Bekasi tentang GERMAS dan bisa mensosialisasikan kepada keluarga dan linkungannya.

Tujuan umum dari kegiatan ini adalah memunculkan kesadaran pada masyarakat dalam mencegah penyakit. Melakukan olahraga teratur dan pemeriksaan kesehatan secara rutin akan lebih menghemat biaya jika dibandingkan dengan mengobati. Hidup sehat dengan melakukan aktivitas fisik minimal 30 menit setiap hari, 
konsumsi sayur dan buah setiap hari, agar sehat dan cerdas, serta cek kesehatan rutin untuk mengontrol tekanan darah, gula darah, kolesterol yang ada dalam tubuh kita (Kemenkes RI, 2017). Pengabdian kepada masyarakat bertujuan untuk meningkatkan pengetahuan, sikap dan perilaku masyarakat sejak dini melalui gerakan masyarakat hidup sehat (GERMAS) (Ambarwati \& Prihastuti, 2019).

Tujuan khusus dari program GERMAS adalah menurunkan beban penyakit, menghindarkan terjadinya penurunan produktivitas penduduk, dan menurunkan beban pembiayaan pelayanan kesehatan karena meningkatnya penyakit dan pengeluaran kesehatan menyatakan bahwa dalam kehidupan sehari-hari, praktik hidup sehat merupakan salah satu wujud revolusi mental GERMAS mengajak masyarakat untuk membudayakan hidup sehat, agar mampu megubah kebiasaan-kebiasaan atau perilaku tidak sehat. Budayakan hidup sehat dengan melakukan langkah kecil melalui perubahan pola hidup ke arah yang lebih sehat (Kemenkes RI, 2017). Selain itu, kegiatan pengabdian masyarakat ini bertujuan mensosiaslisasikan protokol kesehatan untuk mencegah penularan COVID-19 yang mulai mewabah di Indonesia.

Seiring mewabahnya virus corona atau COVID-19 ke berbagai negara, Pemerintah Republik Indonesia menerbitkan protokol kesehatan. Protokol tersebut akan dilaksanakan di seluruh Indonesia oleh pemerintah dengan dipandu secara terpusat oleh Kementerian Kesehatan (Desi Citra Dewi, Jesika Setyani, 2020).
Adapun salah satu protokolnya yaitu jika merasa tidak sehat dengan kriteria demam lebih dari $38^{\circ} \mathrm{C}$, batuk, flu, nyeri tenggorokan maka beristirahatlah yang cukup dirumah dan minumlah air yang cukup. Gunakan masker apabila tidak memiliki masker, hendaknya mengikuti etika ketika batuk dan bersin yang benar dengan cara menutup hidung dan mulut dengan tisu, lengan atas bagian dalam. Bila merasa tidak nyaman dan masih berkelanjutan dan disertai sesak nafas maka segerakan diri untuk memeriksakan kesehatan di fasilitas pelayanan kesehatan. Dan usahakan untuk tidak menaiki kendaraan massal. Sebagaimana protokol diatas maka dapat diambil kesimpulan mengenai penanggulangan dan pencegahan COVID-19 secara umum yang benar adalah sebagai berikut: (1) Rajin mencuci tangan; (2) Kurangi berinteraksi dengan orang lain; (3) Gaya hidup sehat makan, tidur, olahraga untuk imunitas tubuh; (4) Jaga jarak aman 1 meter dengan orang yang batuk/bersin; (5) Hindari kerumunan; (6) Hindari menyentuh mata, hidung dan mulut; (7) Hindari bepergian ke daerah terjangkit atau bila sedang sakit; (8) Jangan berbagi barang pribadi; (9) Kurangi berinteraksi dengan orang lain; (10) Gaya hidup sehat; (11) Hindari salaman atau bersetuhan dengan orang lain; (12)bersihkan barang-barang di sekitarmu; (13) Cuci bahan makan setelah dibeli; (14) Hindari berpergian ke daearah terjangkit atau bila sedang sakit; (15) Etika batuk dan bersin; (16) Bila ada gejala segera berobat dan gunakan masker; (17) Lakukan self quarantine jika sedang sakit; (16) Lindungi diri dengan asuransi jiwa (Desi Citra Dewi, Jesika Setyani, 2020). 
Masker dapat membantu mencegah penyebaran virus dari orang yang mengenakannya kepada orang lain. Mengenakan masker saja tidak cukup untuk melindungi diri dari COVID-19, sehingga harus dikombinasikan dengan pembatasan fisik dan kebersihan tangan. Ikuti saran yang diberikan oleh otoritas kesehatan setempat. Pemerintah Indonesia saat ini sudah melakukan upaya untuk memutus mata rantai penularan virus Corona. Imbauan itu menjaga jarak fisik (physical distancing), kerja dari rumah, belajar di rumah, hingga beribadah di rumah terus digaungkan. Hal itu terkait sifat virus Corona yang menular antarmanusia. Penularan bisa terjadi melalui percikan. Itulah mengapa diharapkan warga menjaga jarak fisik dengan sesamanya untuk meminimalisasi risiko terkena percikan (droplet), atau menyentuh benda yang sebelumnya terkena droplet. Dilansir dari CDC, virus Corona dapat tetap hidup di permukaan benda mati selama berjam-jam atau bahkan berhari-hari. Jadi, sangat penting cara mengetahui bagaimana cara mencegah penyebaran virus corona (Desi Citra Dewi, Jesika Setyani, 2020) .

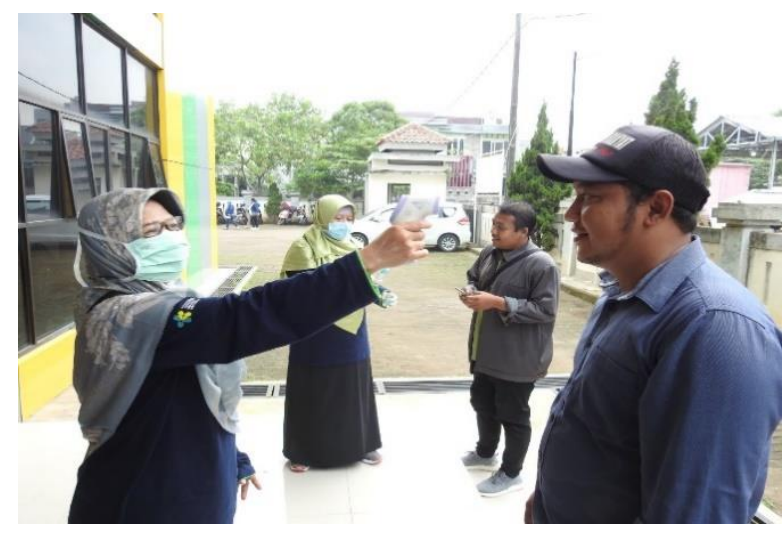

Gambar 1. Pemeriksaan Kesehatan

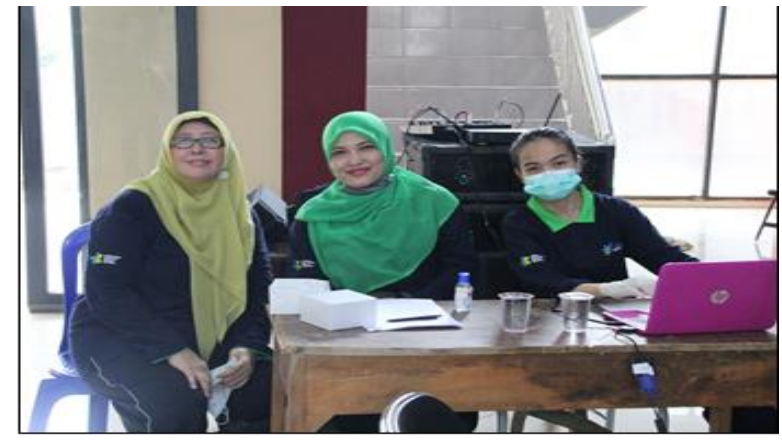

Gambar 2. Persiapan Kegiatan Germas

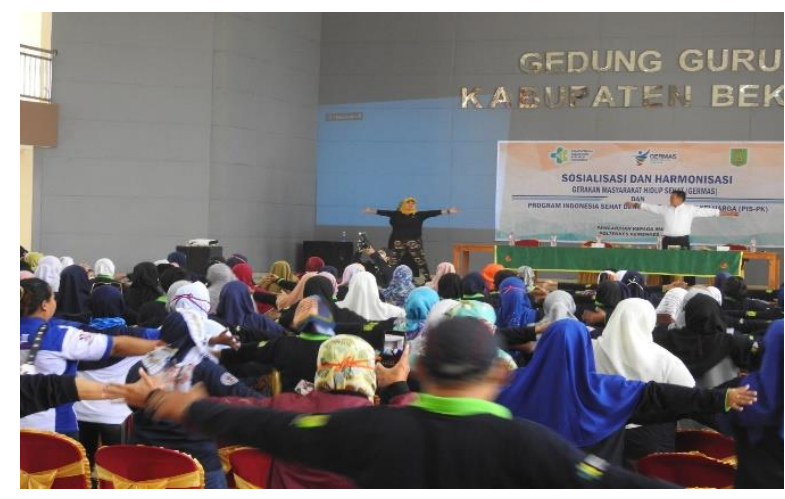

Gambar 3. Foto Senam Germas

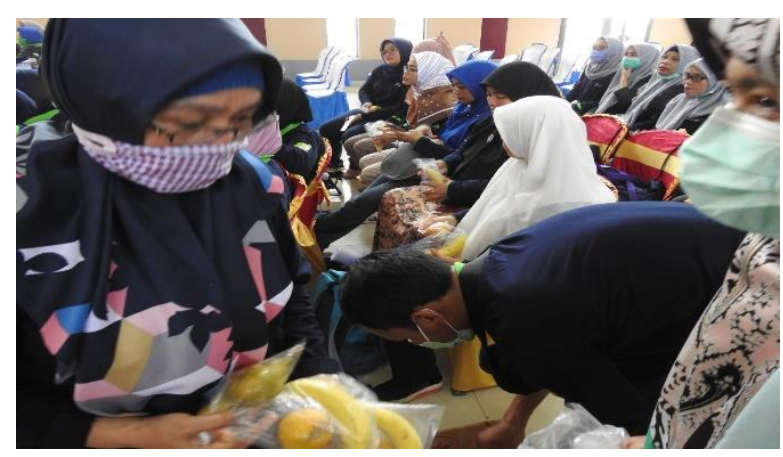

Gambar 4. Foto Makan Buah Bersama

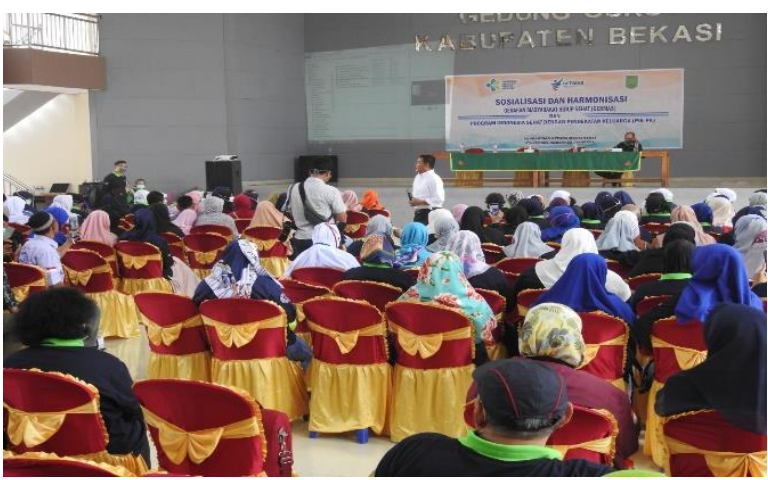

Gambar 5. Foto Pemberian Materi Germas 


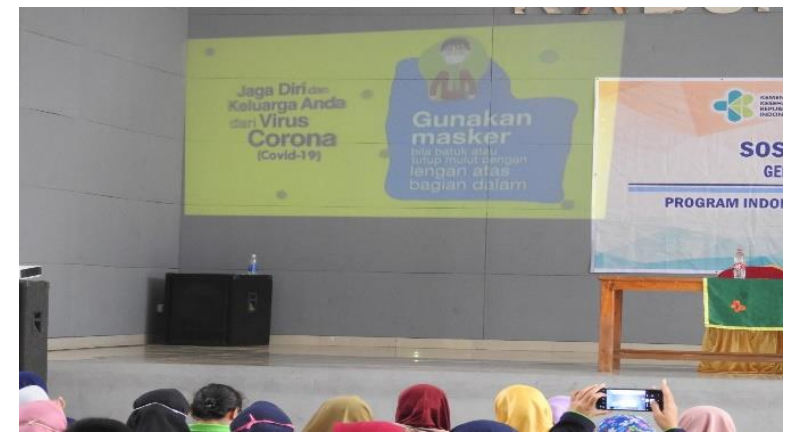

Gambar 6. Foto Pemutaran Video Pencegahan COVID-19

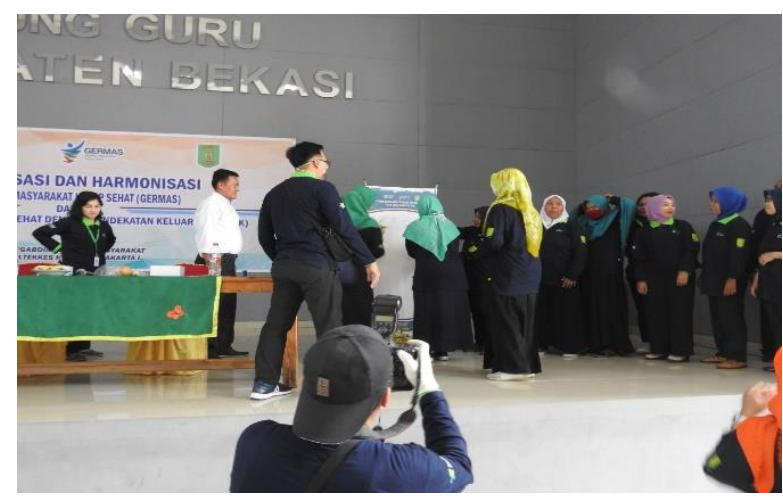

Gambar 7. Foto Penandatanganan Pakta Integritas

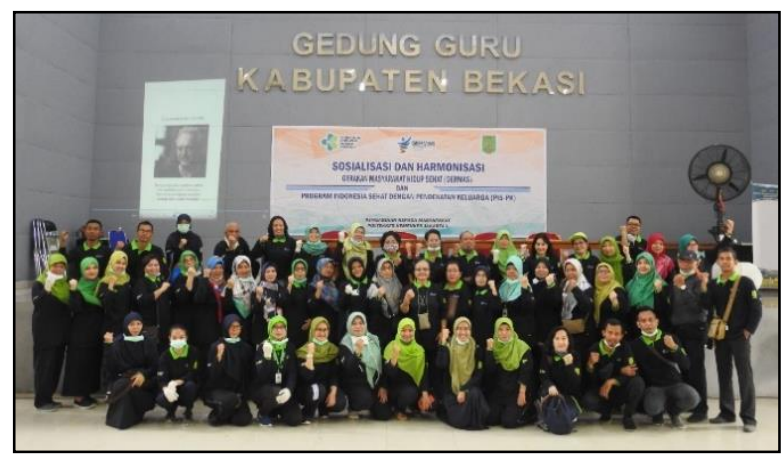

Gambar 8. Foto Bersama

\section{Simpulan dan Saran}

Kegiatan Pengabdian Kepada Masyarakat telah dilaksanakan di wilayah kerja Dinas Kesehatan Bekasi dengan tema Sosialisasi dan Harmonisasi Gerakan Masyarakat Hidup Sehat (Germas) Dengan Program Indonesia Sehat Dengan Pendekatan Keluarga (PIS-PK) Pada Awal Masa Pandemi COVID-19 Di Tambun Bekasi.
GERMAS mengajak masyarakat membudayakan hidup sehat, agar mampu mengubah kebiasaan- kebiasaan atau perilaku tidak sehat. Masyarakat dapat melakukan langkah kecil melalui perubahan pola hidup sehat dengan melakukan langkah kecil melalui perubahan pola hidup ke arah yang lebih sehat. Kegiatan ini memberikan pengetahuan dan pemahaman tentang GERMAS pada karyawan/karyawati pabrik mensosialisasikan kepada keluarga dan lingkunganya.

Dengan adanya kegiatan pengabdian masyarakat dengan tema Sosialisasi dan Harmonisasi Gerakan Masyarakat Hidup Sehat (Germas) Dengan Program Indonesia Sehat Dengan Pendekatan Keluarga (PIS-PK) Pada Awal Masa Pandemi COVID-19, diharapkan karyawan dan karyawati dapat melaksanakan GERMAS dan menerapkan protokol kesehatan pada masa pandemic COVID-19 dalam kehidupan sehari-hari untuk meningkatkan taraf kesehatan masyarakat.

\section{Daftar Pustaka}

Ambarwati, E. R., \& Prihastuti. (2019). Gerakan masyarakat hidup sehat (germas) mencuci tangan menggunakan sabun dan air mengalir sebagai upaya untuk menerapkan perilaku hidup bersih dan sehat (phbs) sejak dini. Celebes Abdimas: Jurnal Pengabdian Kepada Masyarakat, $\quad 1(1), \quad 45-52$. http://journal.lldikti9.id/CER/index

Cahyani, D. I., Kartasurya, M. I., \& Rahfiludin, M. Z. (2020). Gerakan Masyarakat Hidup Sehat dalam Perspektif Implementasi Kebijakan (Studi Kualitatif). Jurnal Kesehatan Masyarakat Indonesia, 15(1), 10. https://doi.org/10.26714/jkmi.15.1.2020.10-18

Desi Citra Dewi, Jesika Setyani, S. Y. (2020). Cara pencegahan penyebaran COVID-19. Universitas Pamulang, 1(1), 111-115. 
Kemenkes RI. (2017). Warta Kesmas: GERMAS. Kementrian Kesehatan RI, Edisi 01.

Kementrian Kesehatan Republik Indonesia. (2018). Germas wujudkan indonesia sehat. In Artikel Kesehatan (pp. 1-9).

Kemkes. (2016). GERMAS Wujudkan Indonesia Sehat. $\quad 15 \quad$ November 2016. https://www.kemkes.go.id/article/view/16111 500002/germas-wujudkanindonesiasehat.html

Tim Kerja Kementerian Dalam Negeri. (2013). Pedoman Umum Menghadapi Pandemi COVID-19 Bagi Pemerintah Daerah : Pencegahan, Pengendalian, Diagnosis dan Manajemen. Journal of Chemical Information and Modeling, 53(9), 1689-1699. https://doi.org/10.1017/CBO9781107415324. 004 